\title{
Judges as Bad Reviewers: Fair Use and Epistemological Humility
}

Rebecca Tushnet

Georgetown University Law Center, rlt26@law.georgetown.edu

Georgetown Public Law and Legal Theory Research Paper No. 13-020

This paper can be downloaded free of charge from:

https://scholarship.law.georgetown.edu/facpub/1186

http://ssrn.com/abstract=2230071

25 Law \& Lit. 20-32 (2013)

This open-access article is brought to you by the Georgetown Law Library. Posted with permission of the author. Follow this and additional works at: https://scholarship.law.georgetown.edu/facpub

Part of the Constitutional Law Commons, and the Intellectual Property Law Commons 


\title{
Judges as Bad Reviewers: Fair Use and Epistemological Humility
}

Rebecca Tushnet*

\begin{abstract}
The future of fair use depends on whether judges act like bad reviewers, or whether they behave differently in interpreting challenged works than they do in almost every other aspect of judging. Ordinarily, judges are asked to produce definitive answers about the meanings of texts. But when it comes to literary judgments, the bad reviewer is the one who insists that a work has only one meaning, and announces the bottom line as if it were an absolute. A good reviewer explains the sources of her judgment, making room for other interpretations. This is also what is necessary to a good fair use analysis.

Unfortunately, copyright fair use cases rarely acknowledge multiplicity of meaning. Through discussion of fan-made music videos, this short commentary shows how transformative uses routinely invite multiple interpretations, just as "original" works do. As a result, a fair use analysis that insists on reducing works to single meanings will predictably fail in the aim of protecting transformative works that add new meanings or messages. The proper approach is epistemological humility: when reasonable audience members could discern commentary on the original work, a court should find transformation, even when other reasonable audience members could disagree.
\end{abstract}

Keywords: copyright / fair use / transformative use / epistemological humility

For a brief commentary, it seems appropriate to start with a provocative statement: the future of fair use as a formal doctrine in the United States depends on whether judges act like bad reviewers on Amazon.com, or whether they behave differently in interpreting challenged works than they do in almost every other aspect of judging.

Ordinarily, judges are asked to produce definitive answers about the meanings of texts, and there are both good reasons for them to do so and

Law \& Literature, Vol. 25, Issue I, pp. 20-32. ISSN I535-685x, electronic ISSN I54I-260I. (C) 2013 by The Cardozo School of Law of Yeshiva University. All rights reserved. Please direct all requests for permission to photocopy or reproduce article content through the University of California Press's Rights and Permissions website, at http://www.ucpressjournals.com/reprintinfo.asp. DOI: IO.I525/lal.20I3.25.I.20. 
a number of tools that, though highly manipulable in many cases, are wellestablished ways of fixing meaning. When a contract promises to deliver "chickens," what does that mean? ${ }^{1}$ If it means young chickens and the defendant supplied mature chickens, then the defendant breached the contract; if "chickens" also includes mature chickens, then the defendant performed. Fixing meaning is necessary for the court to do its job, and courts can use dictionary meanings, standard commercial practice, the parties' course of dealings, and other evidence to do that job. ${ }^{2}$ (My claim here does not depend on the existence of true right answers. Many legal claims are indeterminate and multiple outcomes could be justified in many cases, but my point is that an outcome resting on a single specific interpretation of the relevant documents is the regular result of the legal process, and that most lawyers generally think that having a fixed meaning is good or at least necessary for the law to function. ${ }^{3}$ )

There are, to be sure, occasional instances where a judge concludes that fixing meaning is impossible, but that usually means that the court will find that there is nothing for the law to regulate. In one famous contracts case, each of the parties was thinking of a different ship named Peerless as the relevant subject of the contract, and neither knew about the other Peerless. The court found that no contract had formed and thus that there was nothing to enforce. ${ }^{4}$

In advertising law, only claims that are sufficiently well-defined can be regulated at all - terms that are vague, general, or likely to be understood in different ways by different consumers can't be held to be false advertising. Such claims are mere puffery, and the law won't intervene to stop them, conclusively presuming that no reasonable consumer could be misled by puffery. ${ }^{5}$

In copyright law, judges regularly disclaim any intent or right to evaluate the quality of art, ${ }^{6}$ even though they are often doing so implicitly. ${ }^{7}$ Alfred Yen posits that judges in copyright cases are eager to fix the meaning of works, because the alternative to a single fixed meaning seems to be the postmodern nightmare in which nothing is certain and communication is impossible. ${ }^{8}$ But that is what I mean when I talk about the bad reviewer on Amazon.com: when it comes to literary judgments, the bad reviewer is the one who insists that a work has only one meaning, and announces the bottom line as if it were an absolute. A good reviewer explains the sources of her judgment, making room for other 
interpretations, which may be one reason that a well-written negative review can be extremely helpful to someone deciding to go ahead and buy the book anyway.

Unfortunately, copyright fair use cases rarely acknowledge multiplicity of meaning. Instead, even a defendant-favorable fair use case tends to fix one meaning to the plaintiff's work and another meaning or purpose to the defendant's work, and then declare them different enough that the defendant's use is transformative and therefore fair. ${ }^{10}$ When the defendant loses, the court tends to determine that the meaning of the works is the same, ${ }^{11}$ taking a universalist perspective that denies that different observers might generate different meanings from the same view.

Peter Jaszi argues that the United States may be moving toward a postmodern copyright, ${ }^{12}$ with specific reference to the Second Circuit Court of Appeals ruling in Blanch v. Koons, ${ }^{13}$ which found that appropriation artist Jeff Koons made fair use of a copy of a fashion photograph in his painting Niagara. Appropriation art has certainly been associated with postmodernism's challenges to the hierarchy of high and low. But Jaszi also identifies “[r]ejection of claims based on 'authority' and 'expertise,' including claims relating to interpretation" 14 as a key characteristic of postmodernism, which instead promotes a proliferation of meanings. In that sense, Blanch is not postmodern. The court deferred to Koons on the meaning of and justification for his copying. Shifting to a particular expert, the artist himself, the court left the structure of expertise intact.

As Jaszi explains, the court gave "considerable deference" to Koons's own explanation of why he used Blanch's image, taking Koons's "selfexpressed claims as an interpreter and repurposer of existing content very seriously." 15 Agreeing with Koons's interpretation, the court concluded that "we need not depend on our own poorly honed artistic sensibilities ... . [W] have been given no reason to question his statement that the use of an existing image advanced his artistic purposes." 16 Whereas Jaszi argues, optimistically, that the decision is a harbinger of "an approach that distributes attention and concern across the full range of participants in the processes of cultural production and consumption," 17 fair use was determined not on the basis of potential audiences' understandings of new meanings from the accused work, but on the ability of the artist to express his intentions. The only audience reaction that mattered was Koons's reaction to Blanch's work, because he then created a new work in response. 
Thus, rather than accepting that multiple meanings and interpretations can coexist, the court picked a side in a contest about true meaning, not unlike a ruling in a contracts case.

But multiple interpretations do exist, and some of them operate in areas where fair use is clearly foundational to the artistic endeavor. Remix culture, where debts to earlier sources are not just inherent or acknowledged but flaunted, and where copying often takes place in large chunks rather than the more classical reference or variation, relies heavily on fair use (and even more on copyright owners' toleration, since most remix artists lack the resources to fight in the name of fair use). I will focus here on one remix subculture that shows the necessity of acknowledging the existence of multiple reasonable interpretations if fair use is to have continued purchase as a means of protecting subsequent creators.

Today, a largely female community of artists known as "vidders" creates vids: re-edited footage from television shows and movies, set to music that directs viewers' attention and guides them through the appropriated images. This practice can trace its genealogy to the early I970s, when it featured slideshows carefully coordinated with music. ${ }^{18}$ A vid, Francesca Coppa has written, is an argument made through quotation and narrative. ${ }^{19}$ Tisha Turk draws attention to the ways in which re-editing visuals and changing the soundtrack serve to transform the original narrative in ways that conventional text-based literary theories find difficult to recognize:

[A] vid always represents at least two stories: the story contained within the original source text, and the story of the vidder's response to and transformation of that text at the level of narration. H. Porter Abbott has observed that the burden of narration in film and television is borne not by a speaker but "by the camera (the angles, duration, and sequencing of what it sees) and not uncommonly by music"; these elements of discourse are exactly what vidders alter. A vidder chooses which camera angles to keep or discard, how long each clip should be, and what order those clips should be presented in; and of course she also adds a soundtrack, a song that provides a voice for a character or in some cases for the vidder herself. ${ }^{20}$

By changing editing and music, the vidder changes meaning. But how would a court treat the argument that the vidder's work is transformative? The answer depends in significant part on whether the court would be able to recognize that different people receive the same work in varying ways. 
Vids often depend on close readings of the underlying text, as well as embeddedness in specific communities of fans, and can seem unintelligible or meaningless to people who aren't aware of the context. In one striking instance, a Star Trek vid set to the Nine Inch Nails song "Closer" constructed a scenario in which Spock sexually assaulted Kirk during his pon farr (biologically mandated "time of mating”). The vid crossed over from the Star Trek vid community to a much larger audience on YouTube, where many people considered it a joke rather than a reading embedded in a forty-year history of Kirk/Spock slash and pon farr stories. $^{21}$

In a more recent example, the artist Gianduja Kiss made a vid, "It Depends on What You Pay." The vid illustrates how the television show Dollhouse, ${ }^{22}$ created by critically acclaimed TV auteur Joss Whedon, depended on a premise that was fundamentally about rape. On the show, characters repeatedly had their minds wiped and personalities implanted, often to fulfill another's sexual desires. The show tried very hard to distance itself from rape both by appealing to concepts of prior consent (even as the narrative explained that, at minimum, several key characters had not consented to this treatment) and by defining and distinguishing "real" rapists from the other people responsible for the scenario. "It Depends on What You Pay" sets scenes from Dollhouse to a song from the original version of The Fantasticks. ${ }^{23}$ The song is about - indeed, it celebratesrape. The opening lyrics are:

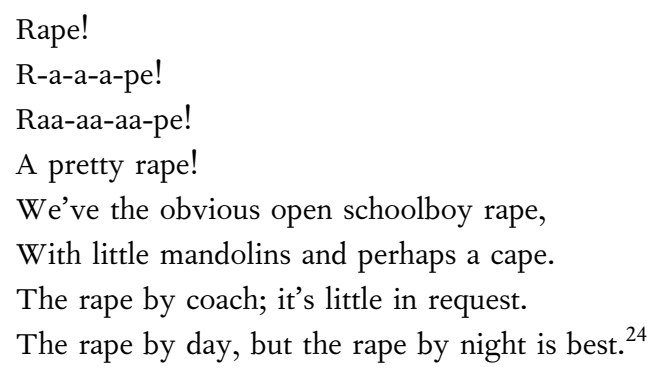

Gianduja Kiss edits these lines to accompany scenes of apparently consensual, tender encounters that in fact involve the un-consenting, brainwashed "dolls," as well as scenes that showcase actresses' bodies for the audience's delectation. The vid quickly moves to scenes of physical and sexual violence, highlighting the continuity between the coerced happiness and the coerced suffering experienced by the dolls. The juxtaposition of this now- 
suppressed song with the images from Dollhouse forces the ugly premise of the show to the surface.

When the vid crossed over from the vidding community to the more general Joss Whedon fan community, many commenters took issue with the vid, on two distinct grounds. First, the vid said nothing new, because Dollhouse was obviously a rape narrative already. Second, the vid constituted unfair criticism because the show was clearly not about rape at all. ${ }^{25}$ The second response demonstrated the insufficiency of the first. Many people wanted to watch Dollhouse and also absolve themselves of enjoying a rape narrative. The vid itself argued that Dollhouse was part of rape culture: a failure to see rape as rape, which the holders of the second view then enacted.

Relatedly, when a videomaker created a remix showing James Bond's use and abuse — sexual and physical_ of women, some of the responses on YouTube read the remix as a celebration of James Bond rather than as a criticism. As Elisa Kreisinger explained,

By isolating (and occasionally repeating) the images of glorified aggression, objectification and, as the artist puts it, "womanizing", the remix creates a rarely acknowledged but more accurate portrayal of Bond's misogynistic masculinity... . Among the male commentors [on] the original remix, there seemed to be very little wrong with the James Bond brand of masculinity [the videomaker] created. In fact, the highest rated and most recent comments illustrated that viewers did not see this remix as a critique but a celebration of Bond's treatment of women. ${ }^{26}$

While Kreisinger saw a very clear exposé and critique of misogyny and James Bond-style masculinity, that meaning was opaque to numerous other viewers. This is not just a matter of naive versus sophisticated readings. It would have very real legal consequences in the event the remix was challenged by the owners of the copyrights in the James Bond films. If a court were to accept the reaction of some viewers that these vids merely reinforced their impressions of the original, the implication would be that the vids were not transformative - they would not add a new meaning or message that was not to be found in the original — and thus not fair use.

The district court in Salinger $v$. Colting applied exactly this mistaken reasoning when finding that the book 60 Years Later was a mere infringing sequel to The Catcher in the Rye, denying fair use because it considered that 
a sophisticated reader would have automatically understood the defendant's alleged critique without any need for the defendant's copying. ${ }^{27}$ Rejecting the defendant's claim that 60 Years Later was transformative because it exposed and highlighted the ultimate ridiculousness and failure of Holden Caulfield's angst, the court reasoned that "Holden Caulfield as delineated by Salinger was already often 'miserable' and 'unconnected' as well as frequently 'absurd[ ]' and 'ridiculous,' as Colting says of his elderly version of the character... . [T] hose effects were already thoroughly depicted and apparent in Salinger's own narrative about Caulfield."28

The court here intervenes in a literary dispute. Although some people surely always saw Caulfield as a pathetic loser, others disagreed. ${ }^{29}$ The problem was not that the court was a bad art critic. I'm inclined to agree that Holden was always pathetic, and certainly this response strikes me as well within the range of understandable critical reaction to The Catcher in the Rye. But the court was a bad reviewer, unable to see the ways in which other people might think differently. The disagreement over the reception of the original - in which Holden is a cultural hero and rebel to some, even as he is a pure loser to others - itself demonstrates that a version of Holden Caulfield focused on his pitiable and failed life is a critical intervention into an ongoing debate.

The history of parody and similar forms is one in which defenders of a targeted work always have available the responses, "That's not really in there; you're seeing things!" and "That's obvious; your so-called parody is not subverting anything." Converted into legal reasoning, both these responses could underlie a finding that a new work was not transformative of an old one. ${ }^{30}$ Yet the interaction between those responses, as with "It Depends on What You Pay," can demonstrate how the new work is transformative by making parts of the old more salient (and more uncomfortable for its fans).

To take a literary example, before Thomas Dixon wrote The Clansman ${ }^{31}$ (made famous in film as Birth of a Nation), he wrote a "sequel" to Harriet Beecher Stowe's Uncle Tom's Cabin. Dixon intended to refute Stowe's novel by turning Simon Legree into a carpetbagger and defending the honor of the South. A number of reviewers saw his book as a superior successor to Stowe's, though reactions were divided. ${ }^{32}$ Many others also rewrote Uncle Tom's Cabin to criticize the novel and defend slavery, often styling the results as "sequels," suggesting that they could be read either as 
criticism or as logical extension. ${ }^{33}$ Essentially, some authors and audiences found in Stowe's original work fodder for pro-slavery narratives, despite both her intent and the reactions of other, larger audiences. Consider also whether a modern reader might not agree with aspects of Dixon's reading, though for different reasons, because of the ways in which Stowe used and shaped stereotypes of African Americans.

This pattern of multiple interpretations appears with other works, from Don Quixote to works by Alexander Pope such as The Rape of the Lock. ${ }^{34}$ Nabokov's estate disputed whether the book Lo's Diary was a transformative revision of Lolita or simply a juvenile misreading of Nabokov's work of genius. ${ }^{35}$ The estate's position was that Lolita did not need to be rewritten from the perspective of Dolores Haze to demonstrate the monstrousness of Humbert Humbert, because he was already a monster. Yet, from the beginning, critics have worried that Lolita makes Humbert too sympathetic. ${ }^{36}$ Even individual understandings of whether work is transformative or simply imitative can change over time: noted art critic Douglas Crimp first read Robert Mapplethorpe's photography as simply copying, rather than commenting on, classical styles; later, he came to understand how Mapplethorpe radically changed the meaning of those styles by addressing the spectator as a homosexual subject. ${ }^{37}$

Copyright rarely confronts this excess of meaning even though, as a general rule, creative works - especially those influential enough to provoke creative responses from other people_ can be read in multiple different ways. But the instability of meaning, if unacknowledged, creates a fault line in fair use. Copyright doctrine tells us that a use is more likely to be fair when it targets something that is, in some sense, in the original work rather than using the original as a launching point for critiquing or discussing an unrelated idea. ${ }^{38}$ Courts aren't exactly looking for "new" meaning, but more for excavation of existing meaning or identification of structures and concepts in the original work that are susceptible to particular critical interpretations. This in turn means that the transformative user will readily be subject to the criticism that she didn't say anything we (who are of course perceptive and thoughtful) did not already know. Without recognizing that works mean different things to different people, transformativeness as a concept is at war with itself.

To work as an expression-promoting concept, transformativeness must be recognized as highly variable and even audience-specific. The media 
studies literature has shown that different audiences read mainstream works differently, meaning that there is no one message that a transformative user could then reject and criticize. ${ }^{39}$ For example, prejudiced and unprejudiced viewers ascribed different meanings to All in the Family, as evidenced by the fact that "some viewers write letters ... which applaud Archie for his racist viewpoint, while others applaud the show for effectively making fun of bigotry." ${ }^{40}$ Viewers' perception of the program's intent to satirize Archie Bunker's prejudices was greatest among nonprejudiced viewers and least among prejudiced viewers. ${ }^{41}$

Indeed, it's possible to read many popular works in directly contradictory ways - this openness may be part of why they are popular. But this multivalence should not insulate them from transformative uses. There is room for contradictory transformative reactions to the original, even when some viewers think that a particular remix only reiterates what's already present in the original. This desire to read a work as supporting one's own commitments may also do something to explain why satisfied fans of Dollhouse and James Bond didn't see anything legitimate or critical about the respective vids. Having already been satisfied with the views expressed in the original, they were less likely to perceive criticism or alternative readings as justified.

Although it would require a kind of epistemological humility that we don't expect - and don't often want - from judges in other cases, a fair use analysis sensitive to how creative works make meaning would be much more open to multiple interpretations. In Campbell v. Acuff-Rose Music (1994), the Supreme Court case that elevated transformativeness to a key component of fair use, Justice Souter wanted to ensure that courts favored parody (which he defined as targeting the original work itself) above mere satire (which he defined as using the original work as a vehicle to attach something else) in the transformativeness inquiry. ${ }^{42}$ Among other things, this formulation ignored the difficulty of distinguishing parody from satire in both literary criticism and law. ${ }^{43}$ However, his use of the passive voice signals the deeper instability in the case: "The threshold question when fair use is raised in defense of parody is whether a parodic character may reasonably be perceived." 44 Reasonably be perceived by whom?

I propose that when reasonable audience members could discern commentary on the original work, a court should find favored "parody," even when other reasonable audience members could disagree. This would 
require adhering to the majority opinion, in contrast to the narrow and unitary vision of transformativeness expressed by Justice Kennedy in his concurrence, where he cautioned that " $[\mathrm{m}]$ ore than arguable parodic content should be required to deem a would be parody a fair use ... . [D]oubts about whether a given use is fair should not be resolved in favor of the selfproclaimed parodist." 45 Kennedy was afraid of letting meaning get out of hand, but he was far too late for that.

As I noted earlier, nondiscrimination is a fundamental principle of modern copyright law: courts are not supposed to be art critics. ${ }^{46}$ That doesn't mean they will, or indeed can, avoid making aesthetic judgments. However, to make fair use work, courts should assess transformativeness from multiple perspectives, with attention to what different audiences might see in a work and in an allegedly transformative remix of that work. ${ }^{47}$ What is needed is a greater degree of epistemological humility, the kind that a good reviewer has. There is some risk that this approach will simply transfer the problem to defining who counts as a "reasonable" audience member, but the existence of communities of practice-whether appropriation artists, vidders, or others - who react to the new work as having a different meaning than the original could help establish that such audiences are both reasonable and real.

The current version of transformativeness tends to involve a fair amount of courts knowing it when they see it. ${ }^{48}$ But as Catharine MacKinnon says, they may not know what I know when I see what I see. Only deliberate attention to the multiple ways in which audiences react both to plaintiffs' works and to defendants' work can allow fair use to promote a truly robust creative environment in which multiple interpretations flourish.

* Portions of this article are adapted from Rebecca Tushnet, "Scary Monsters: Hybrids, Mashups, and Other Illegitimate Children," 86 Notre Dame Law Review 2133 (2011).

I. See Frigaliment Importing Co. v. B.N.S. Int'l Sales Corp., I90 F.Supp. II6, I17 (S.D.N.Y. I960): "The issue is, what is chicken?"

2. For example, in Nanakuli Paving and Rock Co. v. Shell Oil Co., 664 F.2d 772 (9th Cir. I98I), the court looked to common trade usages to supply meaning to ambiguous terms.

3. For a discussion of the unique power that an adjudicative interpretation has compared to a literary interpretation, see Robin West, Narrative, Authority, and Law (Ann Harbor MI: University of Michigan Press, 1993), 93-94.

4. Raffles $v$. Wichelhaus, 2 H. \& C. 906, 159 Eng. Rep. 375 (Ex. 1864). 
5. An advertiser thus has a privilege "to lie his head off, so long as he says nothing specific." W. Page Keeton et al., Prosser \& Keeton On The Law Of Torts, 5 th ed. (St. Paul MN: West Publishing Co., I984), $756-57$.

6. Bleistein v. Donaldson Lithographing Co., I88 U.S. 239, 25I (1903); Campbell v. Acuff-Rose Music, Inc., 5 10 U.S. 569, 582 (1994).

7. Christine Haight Farley, "Judging Art," 79 Tulane Law Review 805, 807 (2005): “Other jurists and commentators have similarly expressed the view that legal and artistic determinations should not be merged and that judges should refrain from indulging in subjective aesthetic determinations."

8. Alfred C. Yen, "Copyright Opinions and Aesthetic Theory," 7I Southern California Law Review 247 (1998).

9. See Michael Agger, "Awsum Shoes! Is it ethical to fix grammatical and spelling errors in Internet reviews?” Slate Magazine (May Iо, 20II), at http://www.slate.com/id/2293544/ (accessed December 2012).

Io. See Blanch v. Koons, 467 F.3d 244 (2d Cir. 2009).

II. See Friedman v. Guetta, No. CV Io-oooI4 DDP (JCx) (C.D. Cal. Apr. I4, 20II), at http://www. scribd.com/doc/5755I287/Friedman-v-Guetta-C-D-Cal-May-27-20I I (accessed December 20I2); Cariou v. Prince, 784 F.Supp.2d 337 (S.D.N.Y 2011).

I2. Peter Jaszi, "Is There Such A Thing As Postmodern Copyright?" I2 Tulane Journal of Technology and Intellectual Property I05 (2009).

I3. Blanch, supra note Iо.

I4. Jaszi, supra note I2, at 106.

I5. Id. at I1 $3-\mathrm{I} 4$.

I6. Blanch, supra note Io, at 255 (internal citation omitted).

I7. Jaszi, supra note I2, at II6.

I8. Francesca Coppa, "Women, 'Star Trek,' and the Early Development of Fannish Vidding," Transformative Works \& Cultures I (2008), at http://journal.transformativeworks.org/index.php/twc/ article/view/64 (accessed December 20I2).

19. Coppa writes that "vidders use music to interpret a visual source; in other words, the song tells the spectator how to understand the montage the vidder has constructed." Francesca Coppa, "An Editing Room of One's Own: Vidding as Women's Work," 26.2 Camera Obscura I29 (2011).

20. Tisha Turk, "Metalepsis in Fan Vids and Fan Fiction," in Metalepsis and Popular Culture, eds. Karin Kukkonen \& Sonia Klimek (Berlin, New York: Walter de Gruyter \& Co., 20II), 83-I03.

21. See Henry Jenkins, "How to Watch a Fan-Vid," Confessions of an Aca-Fan (Sept. I8, 2006), at http://www.henryjenkins.org/2006/o9/how_to_watch_a_fanvid.html (accessed December 2012).

22. Dollhouse, Fox, 2009.

23. As Gianduja Kiss explains, “By I990, ... 'It Depends On What You Pay' had been largely excised from the show. Recent productions of The Fantasticks either include the song with a different set of lyrics, or delete it entirely and substitute a new song in its place.” Gianduja Kiss, “It Depends on What You Pay,' Monsters from the Vids” (April 25, 2009), at http://www.giandujakiss.com/ index.php? ${ }^{2}=\mathrm{t}=$ videos\&video $=\mathrm{II} 9$ (accessed December 20I2).

24. "It Depends on What You Pay," The Fantasticks, Harvey Schmidt \& Tom Jones, I980.

25. See, e.g., "Comments on 'It Depends on What You Pay,"” Whedonesque (April 27, 2009), at http://whedonesque.com/comments/20046 (accessed December 20I2).

26. Elisa Kreisinger, “The Real James Bond” (April 4, 20II), at http://www.politicalremixvideo. $\mathrm{com} / 20 \mathrm{II} / \mathrm{O}_{4} / \mathrm{O}_{4} /$ the-real-james-bond-2/ (accessed December 20I2).

27. Salinger v. Colting, 64I F. Supp.2d 250, 257-58 (S.D.N.Y. 2009), rev'd on other grounds, 607 F.3d 68 (2d Cir. 20Io) (first alteration in original) (emphasis added) (citation omitted).

28. Id. at 258 . 
29. See, e.g., Jennifer Schuessler, “Get a Life, Holden,” New York Times (June 20, 2009), WK 5, at http://www.nytimes.com/2009/06/2I/weekinreview/2 Ischuessler.html (accessed December 2012).

30. Salinger is an example of the latter ("that's obvious") response, whereas Dr. Seuss Enterprises $v$. Penguin Books USA, Io9 F.3d I394 (9th Cir. I997), is an example of the former ("that's not in there"). In Dr. Seuss, the court found that a parody of the O.J. Simpson trial in which Simpson played the role of the mischievous Cat in the Hat did not serve as a critique of the childish denial of responsibility by the original Cat in the Hat, and that the defendants' claim to critique was mere unconvincing shtick.

3I. Thomas Dixon Jr., The Clansman (Lexington KY: University Press of Kentucky, I906).

32. See Melvyn Stokes, D.W. Griffith's The Birth of a Nation (Oxford, NY: Oxford University Press, 2007), 37, 4I-42; see also Brief for Am. Library Ass'n et al. as Amici Curiae Supporting Appellants at 19-20, Salinger v. Colting, 607 F.3d 68, No. 09-2878-cv (2d Cir. 2010) (recounting the history).

33. See Sarah Robbins, The Cambridge Introduction to Harriet Beecher Stowe (Cambridge MA: Cambridge University Press, 2007), I03.

34. See Simon Dentith, Parody (New York: Routledge 2000), 36: "[P] arody has the paradoxical effect of preserving the very text that it seeks to destroy .... . This can have some odd effects, even running counter to the apparent intentions of the parodist. Thus the classic parody of Don Quixote ... preserves the very chivalric romances that it attacks — with the unexpected result that for much of its history the novel has been read as a celebration of misplaced idealism rather than a satire of it."

35. Pia Pera, Lo's Diary (London: Foxrock Books, 200I). However, Nabokov's heir got to write an introduction about how bad Lo's Diary was as part of the settlement allowing it to be published. See Dmitri Nabakov, “On a Book Entitled Lo's Diary,” Iо3 Evergreen Review (I999), at http:/ / www. evergreenreview.com/103/losdiary/preface.html (accessed December 2012).

36. Michiko Kakutani, “Lo’s Diary’: Humbert Would Swear This Isn't the Same Lolita,” New York Times (Oct. 29, I999), at http://www.nytimes.com/books/99/10/24/daily/102999pera-bookreview.html (accessed December 2012).

37. See Johanna Burton, “Subject to Revision," Artforum (Oct. 2004), reprinted in Appropriation, ed. David Evans (Cambridge MA: MIT Press, 2009) (citing Douglas Crimp, "Photographs at the End of Modernism," in On the Museum's Ruins [Cambridge MA: MIT Press, I993]).

38. See Campbell, supra note 6, at 580-8I (holding that a use is more likely to be fair if it targets something within the original work rather than using the original as a stepping-off point for unrelated commentary); Rebecca Tushnet, "Payment in Credit: Copyright Law and Subcultural Creativity," 70 Law \& Contemporary Problems I35, I6I-62 (2007) (arguing that transformation regularly emerges from highlighting elements in the original).

39. See, e.g., John Fiske, Reading the Popular (New York: Routledge, I989); John Fiske. "TV: Re-Situating the Popular in the People," I.2 Continuum: Australian Journal of Media $\mathcal{E}$ Culture 56 (I987-I988), at http://wwwmcc.murdoch.edu.au/ReadingRoom/I.2/Fiske.html (accessed December 2012).

40. Neil Vidmar \& Milton Rokeach, “Archie Bunker's Bigotry: A Study in Selective Perception and Exposure," 24 Journal of Communication 36 (1974).

4I. Id.

42. Campbell, supra note 6.

43. See Bruce Keller \& Rebecca Tushnet, “Even More Parodic than the Real Thing: Parody Lawsuits Revisited," 94 Trademark Reporter 979 (2004).

44. Campbell, supra note 6, at 582 .

45. Id. at 599 .

46. See id. at 582-83 (quoting Justice Holmes' caution against judging artistic merit in Bleistein $\nu$. Donaldson Lithographing Co., I88 U.S. 239, 25I (1903)). Though nondiscrimination is formally 


\section{Law \& Literature • Volume 25, Number 1}

a foundational principle of modern copyright, many have persuasively argued that artistic judgments of some sort are both pervasive and inevitable in copyright cases. See, e.g., Amy B. Cohen, "Copyright Law and the Myth of Objectivity: The Idea-Expression Dichotomy and the Inevitability of Artistic Value Judgments," 66 Indiana Law Journal I75 (1990). Farley, supra note 7; Yen, supra note 8.

47. Cf. Mattel, Inc. v. Walking Mountain Prods., 353 F.3d 792, 80I (9th Cir. 2003): "While individuals may disagree on the success or extent of a parody, parodic elements in a work will often justify fair use protection .... Allowing majorities to determine whether a work is a parody would be greatly at odds with the purpose of the fair use exception and the Copyright Act."

48. See, e.g., Dr. Seuss Enters. v. Penguin Books, ro9 F.3d 1394 (9th Cir. 1997) (rejecting transformativeness claim out of hand). 